\title{
CLINICO-EPIDEMIOLOGICAL PROFILE, HEALTH CARE UTILIZATION AND PRACTICES REGARDING SNAKE BITE AT ILAM DISTRICT OF EASTERN NEPAL
}

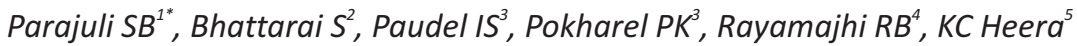

\section{Affiliation}

1. Lecturer, Birat Medical College \& Teaching Hospital, Tankisinuwari, Morang, Nepal

2. Assistant Professor, B. P. Koirala Institute of Health Sciences, Dharan, Sunsari, Nepal

3. Professor, B. P. Koirala Institute of Health Sciences, Dharan, Sunsari, Nepal

4. SMO, World Health Organisation

5. College of Nursing B. P. Koirala Institute of Health Sciences, Dharan, Sunsari, Nepal

\section{ARTICLE INFO}

\section{Article History}

Received : 3 April, 2017

Accepted : 15 June, 2017

Published : 30 August, 2017

(C) Authors retain copyright and grant the journal right of first publication with the work simultaneously licensed under Creative Commons Attribution License CC - BY 4.0 that allows others to share the work with an acknowledgment of the work's authorship and initial publication in this journal.

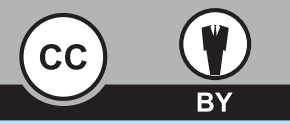

ORA 27

$$
\begin{gathered}
\text { * Corresponding Author } \\
\text { Dr Surya B. Parajuli } \\
\text { Lecturer, Department of Community Medicine } \\
\text { Birat Medical College \& Teaching Hospital } \\
\text { Tankisinuwari, Morang, Nepal } \\
\text { Email: info@suryaparajuli.com.np } \\
\text { ORCID ID: 0000-0003-0386-9273 }
\end{gathered}
$$

\section{Citation}

Parajuli SB, Bhattarai S, Sharma IS, Pokharel PK, Rayamajhi RB, KC Heera. Clinico-epidemiological Profile, Health Care Utilization And Practices Regarding Snake Bite at Ilam District of Eastern Nepal. BJHS 2017;2 (2)3:179- 183.

\begin{abstract}
Introduction

Snake bite is neglected problem of the rural agrarian society of the world. Nepal is one of the vulnerable countries of snakebite. The utilization of health care services and practices regarding snake bite is not known.
\end{abstract}

\section{Objective}

This objective of the study was to explore clinicoepidemiological profile, health care utilization and practices regarding snake bite at Ilam District of eastern Nepal.

\section{Methodology}

This was a cross-sectional study and conducted from $25^{\text {th }}$ March to $25^{\text {th }}$ May 2013 using a systematic random sampling of 300 people from communities of Ilam district. The data was collected after receiving informed consent. The collected data was entered into Microsoft excel and analysed by using SPSS.

\section{Results}

The majority (76.7\%) of the respondents had seen snakes in their locality. The major snake noticed was mountain pit viper (Ovophis monticola)- Grube (94.8\%). Among respondents, $5.3 \%$ had a history of snake bite which was predominant among productive age of 15-39 years. The most common bitten part of the body was leg (56.3\%). There was no any serious injuries and death. Treatment was done by different modalities such as by using local antidote (31.3\%) at the bite site and by soap-clean water ( $25 \%)$. Sixty-nine percent of the snake bite victims utilized modern health care system. Charali snake bite management center, Jhapa was the major treatment center. Seven out of 10 had knowledge of using a tourniquet. After full recovery from a snake bite, 1 out of 5 had avoided milk due to their false belief.

\section{Conclusion}

Active age group was more victimized. The commonest bitten part was a leg. The knowledge of first aid of snake bite was not adequate and many were unaware of post snake bite practices. Reassurance, early first aid and timely transportation to health center save many victims of snake bite.

\section{KEY WORDS}

Geographic locations, Nepal, patient acceptance of health care, snake bites 


\section{INTRODUCTION}

Snakes have been feared, worshiped, or loathed in South Asia from ancient times. In this region snakes remain a painful reality in the daily life of millions of rural peoples. Cobras snakes appear in many tales and myths and are regarded as sacred by both Buddhists and Hindus. Though anti-snake venom is produced in large quantities by several public and private manufacturers however, most victims of snake bite don't have access to quality care. In many countries, both morbidity and mortality due to snake bites are alarming. The snake bite envenoming is the neglected issue of the modern era. ${ }^{1}$ An exact measure of the global burden of snakebite remains limited despite many attempts to estimate it. Apart from few countries, reliable figures on snake bite incidence, morbidity, and mortality are not well defined. ${ }^{2}$ In Nepal, each year more than 20,000 cases of envenoming occur with 1,000 recorded deaths. ${ }^{3}$ The district hospital records review of Nepal showed that national figures underestimated the incidence of snake bite. ${ }^{4}$ In a community based research conducted in southeast Nepal in 2002 found that annual incidence and mortality rates of snake bite envenoming was $1,162 / 100,000$ and 162/100,000, respectively. ${ }^{5}$ In Nepal and Bangladesh, envenoming by green pit vipers is very common. ${ }^{4}$ In a study, it was reported that bites by the mountain pit viper (Ovophis monticola) occur in Nepal where it is the most commonly encountered poisonous snake at altitudes of 900-2,700 m. ${ }^{6}$ In a study from hilly region of eastern Nepal, it was reported that many people still use traditional healers service for their day to day health care and the use of government health facility utilization was low as compared to private health care facility. The people having the concept that modern health centres are costly and living for a longer period in that place were the primary user of traditional health care system. This will challenge the modern health care service utilization in eastern Nepal. ${ }^{7}$ In Nepal, snake bite is an important cause of many deaths. It is due to poor health services in rural areas especially for the lack of anti snake venom(ASV) treatment facility. ${ }^{8}$ Hence this study was conducted with the objective to explore clinicoepidemiological profile, health care utilization and practices regarding snake bite at Ilam district of eastern Nepal.

\section{METHODOLOGY}

This study was community-based cross-sectional study and conducted between $25^{\text {th }}$ March to $25^{\text {th }}$ May 2013. The site of study was Pashupatinagar and Fikal community of llam district of eastern Nepal. The systematic random sampling method was used to select 300 household for collection of the necessary information. Data was collected by the house to house visit with pretested questionnaire. The collected data was entered in Microsoft excel and analyzed using SPSS. Ethical clearance was taken from concerned authority and informed consent was taken prior to the study.

\section{RESULTS}

The various socio-demographic characteristics of respondents was presented in table 1 . Regarding distribution of age of respondents more than half (51.3\%) were of age 20 -39 years with mean age of 38.90 years. Majority (58.3\%) of the respondents were male. The major ethnicity was hill Janajati (49\%). The majority (83\%) were literate among whom onefourth were middle school certificate holders. Four in every five respondents were married and living together. Nine out of ten (92\%) head of households was employed and their major occupation was tea plugging and farming.

Table 1: Socio-demographic characteristics of respondents $(n=300)$

\begin{tabular}{|c|c|c|}
\hline Characteristics & Number & Percent \\
\hline \multicolumn{3}{|l|}{ Age (years) } \\
\hline $15-19$ & 20 & 6.7 \\
\hline 20-39 & 154 & 51.3 \\
\hline $40-59$ & 96 & 32.0 \\
\hline$\geq 60$ & 30 & 10.0 \\
\hline Mean \pm S.D. & \multicolumn{2}{|c|}{$38.90 \pm 15.16$} \\
\hline \multicolumn{3}{|l|}{ Sex } \\
\hline Male & 175 & 58.3 \\
\hline Female & 125 & 41.7 \\
\hline \multicolumn{3}{|l|}{ Case / Ethnicity } \\
\hline Brahmin/Chhetri & 115 & 38.3 \\
\hline Hill Janajati & 147 & 49.0 \\
\hline Terai & 23 & 7.7 \\
\hline Dalit & 15 & 5.0 \\
\hline \multicolumn{3}{|l|}{ Marital Status } \\
\hline Married \& Living together & 253 & 84.3 \\
\hline Widowed/Separated & 11 & 3.7 \\
\hline Never Married & 36 & 12.0 \\
\hline \multicolumn{3}{|l|}{ Major Occupation of $\mathrm{HOH}$} \\
\hline Employed & 276 & 92.0 \\
\hline Unemployed & 24 & 8.0 \\
\hline \multicolumn{3}{|l|}{ Literacy Status } \\
\hline Illiterate & 51 & 17.0 \\
\hline Literate & 249 & 83.0 \\
\hline Graduate/Post & 25 & 10.0 \\
\hline graduagte & 60 & 24.1 \\
\hline Certificagte Level & 50 & 20.1 \\
\hline High School & 63 & 25.3 \\
\hline $\begin{array}{l}\text { Middle School } \\
\text { Primary School }\end{array}$ & 51 & 20.5 \\
\hline
\end{tabular}


Figure 1 shows the respondents who had seen asnake in their locality. Among the respondents, almost every 8 out of 10 (76.7\%) had seen snakes in their locality.

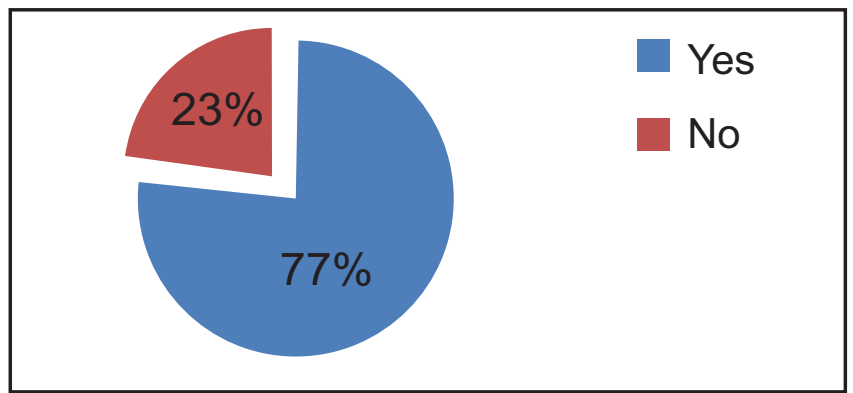

Figure 1: Respondents who had seen snake in their locality $(n=300)$

As shown in figure 2 and 3,the major snake identified was Gurbe (mountain pit viper, Scientific name: Ovophis monticola) (95\%) followed by Sabe (eastern trinket snake, Scientific name: Orthriophis cantoris) (3.5\%) and Dhaman (Rat Snake, Scientific name: Ptyas mucosa) (1.8\%). Figure 3 illustrate the Gurbe which was identified in eastern Nepal.

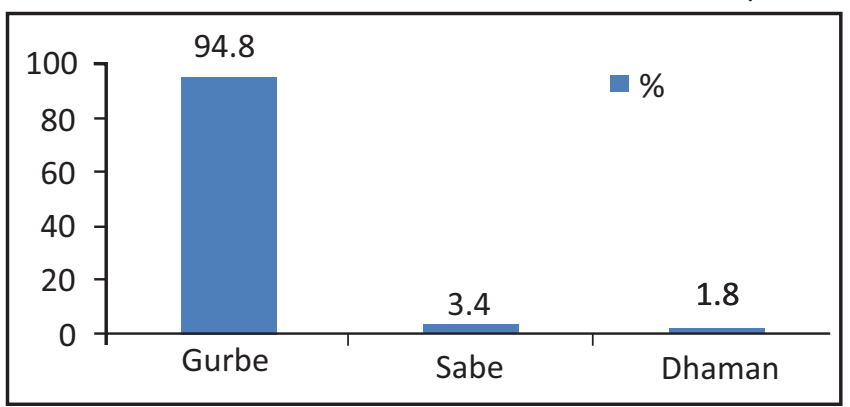

Figure 2: Types of snake seen by respondents $(n=230)$

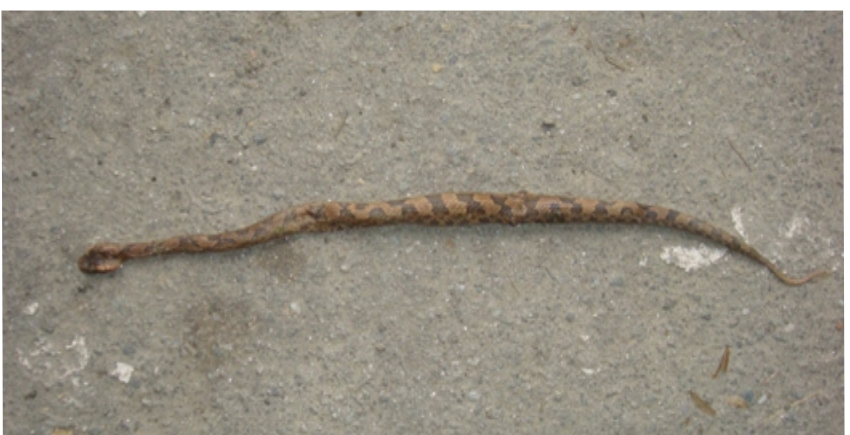

Figure 3: Gurbe (mountain pit viper, Scientific name: Ovophis monticola)

Table 2 provides different characteristics of snake bite. Among the respondent, 16 persons were bitten by a snake. Snake bite was commonest in the active age group of 15-39 years $(43.75 \%)$ with no gender difference. The majority $(56.3 \%)$ were bitten in the leg. None of them have any serious injuries and death. Regarding the first aid measure tourniquet was applied by $31.25 \%$ at the bite site followed by cleaning bite site by soap/clean water (25\%). Among the snake bite victims, the majority $(68.75 \%$ ) received treatment from Charali snake bite management center, Jhapa where anti-snake venom is available. All the victims were completely cured.
Table 2: Snake bite characteristics

\begin{tabular}{|c|c|c|}
\hline Characteristics & Number & Percent \\
\hline \multicolumn{3}{|l|}{ History of snake bite $(n=300)$} \\
\hline Yes & 16 & 5.3 \\
\hline No & 284 & 94.7 \\
\hline \multicolumn{3}{|l|}{ Frequency of snake bite ( $n=16)$} \\
\hline 1 bite & 16 & 100.0 \\
\hline \multicolumn{3}{|c|}{ Age (years)of snake bite victim $(n=16)$} \\
\hline$<15$ & 2 & 12.50 \\
\hline $15-39$ & 7 & 43.75 \\
\hline $40-59$ & 3 & 18.75 \\
\hline$>60$ & 4 & 25.0 \\
\hline \multicolumn{3}{|c|}{ Gender distribution among snake bite ( $n=16)$} \\
\hline Male & 8 & 50.0 \\
\hline Female & 8 & 50.0 \\
\hline \multicolumn{3}{|l|}{ Parts of body bitten $(n=16)$} \\
\hline Hand & 7 & 43.7 \\
\hline Leg & 9 & 56.3 \\
\hline \multicolumn{3}{|l|}{ Snake bite first aid used $(n=16)$} \\
\hline Soap/clean water & 4 & 25.0 \\
\hline Tourniquet & 5 & 31.25 \\
\hline Mud/soil & 1 & 6.25 \\
\hline Nothing & 6 & 37.5 \\
\hline \multicolumn{3}{|c|}{ Snake bite treatment center $(n=16)$} \\
\hline $\begin{array}{l}\text { Charali snake bite treatment } \\
\text { center (Anti-venom available) }\end{array}$ & 11 & 68.75 \\
\hline Local healing & 5 & 31.25 \\
\hline \multicolumn{3}{|l|}{ Outcome of treatment $(n=16)$} \\
\hline Completely cured & 16 & 100.0 \\
\hline
\end{tabular}

Table 3 shows the awareness on snake bite treatment. Regarding awareness on first aid management of snake bite victims, every seven out of 10 responded that tourniquet should be used as a method of first aid. Regarding awareness on post snake bite food taboos, after full recovery from a snake bite, $22 \%$ had a wrong belief of avoiding milk followed by water (6\%). Figure $4 a$, 4 b illustrate the viper bite victims showing their hands.

\section{Table 3: Awareness on Snake bite treatment}

$\begin{array}{lcc}\text { Characteristics } & \text { Number } & \text { Percent } \\ \text { Awareness on snake bite first aid } & & \\ \text { Traditional methods } & 66 & 22.0 \\ \text { Incision and drainage } & 24 & 8.0 \\ \text { Tourniquet } & 210 & 70.0 \\ \text { Post Snake bite food Taboos } & & \\ \text { Avoid Milk } & 66 & 22 \\ \text { Avoid Water } & 18 & 6 \\ \text { Avoid Medicine } & 3 & 1 \\ \text { No Avoidance } & 213 & 71\end{array}$



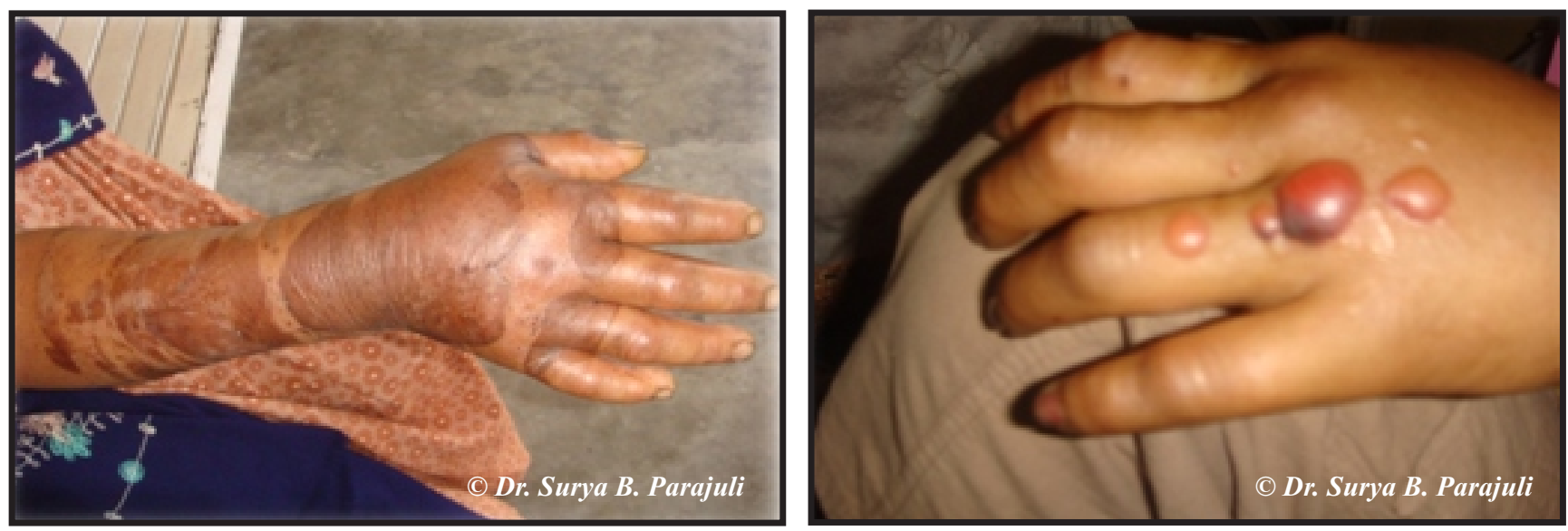

Figure 4a, 4b: Viper bites victims showing their hand at eastern Nepal

\section{DISCUSSION}

In the present study, the majority of the head of households were employed. Ilam is the city which has a rich source of tea farming. Tea farming gives employment to lot of people in Ilam which ultimately strengthen their economic status. Tea plucking was major occupation because of famous tea farming culture in Ilam district. Similar to this study, dominant profession among the victims of snake bite were farmers, plantation workers, herders, fishermen, snake restaurant workers and other food producers. ${ }^{8}$ In this study majority of the snake seen were of viper groups such as Gurbe and Sabe. This is further supported by the studies conducted by Shah KB et a land Tillack F et al where the mountain pit viper encountered at altitudes of 900-2,700 meters was the most common., ${ }^{6,9}$ The present study found that the majority of snake bite envenoming victims were from the productive age of 15-39 years. Similarly to this study, the mean age of snake bite envenoming victims was 32 years. ${ }^{5}$ Almost similar result was found, where majority of the snake bite envenoming victims were in the productive age of 15 and 45 years. ${ }^{10}$ No gender difference on snake bite envenoming was found in the present study. In contrast, the study done by Jarwani B et al showed the majority of the victims were male. ${ }^{10}$ It was found that the snakebite cases were almost equally distributed in both the sexes although, males have shown slightly higher proportion. ${ }^{11}$

The lower extremities were the most common site of snake bite envenoming in our study which is similar to the study by Devkota U N et al. ${ }^{11}$ Similar to this study it was reported that, snake bite was mostly on the lower extremities (83\%). ${ }^{12}$

In the present study, none of the victims had any serious complications and death. It may be due to non-fatal poisoning from viper group of the snake. The timely transfer of snake bite victims to snake bite management center may be the another region behind no serious complication and fatality from snakebite. Palangasinghe DR et al reported a previously healthy male who is young 18 years had bilateral severe pulmonary hemorrhages resulting in a fatal outcome following Russell's viper envenoming. ${ }^{13}$ Seignot Preported 44 year European who was bitten on the foot in Djibouti, probably by an African viper had fatality. ${ }^{14}$
Regarding the use of first aid measure in this study, tourniquets were applied followed by cleaning bite site with soap/clean water. This is a wrong practice of snake bite envenoming first aid management. This study is supported by the study of Deb Prasad Pandey which state that no victims followed the first-aid recommended by World Health Organisation in Nepal. ${ }^{15}$ This is also supported by the study of Hansdak $G$ et al where more than half of snake bite victims used harmful and inappropriate first aid methods after snake bite envenoming. ${ }^{16}$ Two studies in Nepal and Bangladesh showed that $90 \%$ and $98 \%$ of snake bite envenoming, respectively, used tourniquets. ${ }^{17-18}$ The majority of victims of snake bite envenoming first report to traditional healers. Tourniquets were the main first aid measure used by the victims (86\%). ${ }^{19}$ Incisions at and around the bite site were made in $28 \%$ of envenomed victims of snake bites and in $13 \%-14 \%$ of those without signs of snake bite envenoming. ${ }^{18}$ After snake bite envenoming first aid given was use of tourniquet $(16.2 \%)$, local application of chillies, herbal medicine and lime, etc., $(1 \%) .{ }^{10}$ In contrast to the above practice reassurance to the victim, immobilization of the bitten part, applying a pressure bandage and timely referral to the appropriate health centre is a correct technique in snake bite management. ${ }^{20}$ However, time factor plays a very important role in the survival of the victims of snake bite envenoming. The strong aspect of our study was that majority received treatment from Charali snake bite management center which is biggest snake bite treatment centre in eastern Nepal with modern health care system where anti-snake venom is available regularly. Even though the distance was quite long. Cruz LS reported that delay and scarcity of administration of antivenom in victims of snake bite envenoming, poor health care services, and transportation difficulties from rural areas to health centers are important significant factors that contribute to the high case-fatality ratio of snakebite victims. ${ }^{21}$

In this study regarding awareness on first aid management, 70 percent cited the use of tourniquet, 22 percent traditional method and 8 percent of practicing sucking blood by mouth 
from bite site and doing incision and drainage. These first aid practices deteriorates the condition of the victims of snake bite envenoming. We have to encourage them to change this type of awareness on snake bite envenoming. Pandey DP reported that first aid training on snake bite envenoming changes the people's attitude in management of snake bite envenoming victims and this is one of the effective ways in decreasing mortality of snake bite victims. ${ }^{15}$

This research also assessed awareness on post snake bite food taboos, after full recovery. Estimated figure showed that, 22 percent had wrong myths of avoiding milk, 1 percent medicine and 6 percent water. These all myths are wrong. They can continue these food items after full recovery of snake bite envenoming.

\section{CONCLUSION}

The snake bite in the hilly region of eastern Nepal is common. The most common snake reported was Gurbe. The productive age group was the major victims of snake bite. The leg was the common site of envenoming without serious complication and death. Lack of awareness regarding snake bite first aid and post snake bite food consumption practices were common among the surveyed population.

\section{REFERENCE}

1. Simpson ID, Norris RL. The global snakebite crisis--a public health issue misunderstood, not neglected. Wilderness \& environmental medicine. 2009 Spring;20(1):43-56. PubMed PMID: 19364169. Epub 2009/04/15. eng.

2. Chippaux JP. Snake-bites: appraisal of the global situation. Bulletin of the World Health Organization. 1998;76(5):515-24. PubMed PMID: 9868843. Pubmed Central PMCID: PMC2305789. Epub 1998/12/30. eng.

3. WHO. Wkly Epidemiol Rec. 1987

4. Sharma SK, Khanal B, Pokhrel P, Khan A, Koirala S. Snakebitereappraisal of the situation in Eastern Nepal. Toxicon : official journal of the International Society on Toxinology. 2003 Mar 01;41(3):285-9. PubMed PMID: 12565750. Epub 2003/02/05. eng.

5. Sharma SK, Chappuis F, Jha N, Bovier PA, Loutan L, Koirala S. Impact of snake bites and determinants of fatal outcomes in southeastern Nepal. The American journal of tropical medicine and hygiene. 2004 Aug;71(2):234-8. PubMed PMID: 15306717. Epub 2004/08/13. eng.

6. Tillack F SK, Gumprecht A, Husain A. Anmerkungen zur Verbreitung, Morphologie, Biologie, Haltung und Nachzucht der BergGrubenotter Ovophis monticola monticola Sauria. 2003:25-9.

7. Sailesh Bhattarai, Surya Bahadur Parajuli, Rajan Bikram Rayamajhi, Ishwari Sharma Paudel, Nilambar Jha. Health Seeking Behavior and Utilization of Health Care Services in Eastern Hilly Region of Nepal. Journal of College of Medical Sciences-Nepal 2015;11(2).

8. Chaudhary S SS, Chaudhary N, Mahato SK. Snake bite in Nepal. Journal of Universal College of Medical Sciences. 2014;2(7).

9. Shah KB TS. Herpetofauna of Nepal - a conservation companion. Kathmandu, Nepa. The World Conservation Union. 2004.

10. Jarwani B, Jadav P, Madaiya M. Demographic, epidemiologic and clinical profile of snake bite cases, presented to Emergency Medicine department, Ahmedabad, Gujarat. Journal of emergencies, trauma, and shock. 2013 Jul;6(3):199-202. PubMed PMID: 23960378. Pubmed Central PMCID: PMC3746443. Epub 2013/08/21. eng

11. Devkota U N SJP, Kathayat J B. EPIDEMIOLOGY OF SNAKEBITE; A STUDY FROM CHOHARWA ARMY CAMP, SIRAHA, NEPAL. Journal of Nepal Medical Association. 2001;40:57-62.

12. Suleman MM, Shahab S, Rab MA. Snake bite in the Thar Desert. JPMA The Journal of the Pakistan Medical Association. 1998 Oct;48(10): 306-8. PubMed PMID: 10087752. Epub 1999/03/24. eng.

\section{RECOMMENDATIONS}

We recommended conducting series of awareness program on snake bite focusing on tea-pluckers. Proper transportation facility to snake bite victims and local availability of anti-snake venom in primary health care centre is the utmost need.

\section{LIMITATION OF THE STUDY}

Being a short duration study, we are not able to include large geographical area and respondents. There may be a selection bias, as we asked the question to one of the family members. Due to questions related to past events, we could not fully omit the recall bias.

\section{ACKNOWLEDGEMENT}

We would like to thank all the respondents for their kind support and our organisation. Special thanks goes to Prof. Dr. Sanjib Kumar Sharma and Prof. Dr. Anup Ghimire.

\section{CONFLICT OF INTEREST}

We declare no conflict of interest.

13. Palangasinghe DR, Weerakkody RM, Dalpatadu CG, Gnanathasan CA. A fatal outcome due to pulmonary hemorrhage following Russell's viper bite. Saudi medical journal. 2015 May;36(5):634-7. PubMed PMID: 25935188. Pubmed Central PMCID: PMC4436764. Epub 2015/05/04. eng.

14. Seignot $P$, Ducourau JP, Ducrot $P$, Angel $G$, Roussel L, Aubert M. [Fatal poisoning caused by African viper's bite (Echis carinatus)]. Annales francaises d'anesthesie et de reanimation. 1992;11(1):105-10. PubMed PMID: 1443801. Epub 1992/01/01. Envenimation mortelle par une morsure de vipere africaine (Echis carinatus). fre.

15. Pandey DP, Thapa CL, Hamal PK. Impact of first aid training in management of snake bite victims in Madi valley. Journal of Nepal Health Research Council. 2010 Apr;8(1):5-9. PubMed PMID: 21879005. Epub 2010/04/01. eng.

16. Hansdak SG, Lallar KS, Pokharel P, Shyangwa P, Karki P, Koirala S. A clinico-epidemiological study of snake bite in Nepal. Tropical doctor. 1998 Oct;28(4):223-6. PubMed PMID: 9803844.

17. Sharma SK, Koirala S, Dahal G, Sah C. Clinico-epidemiological features of snakebite: a study from Eastern Nepal. Tropical doctor. 2004 Jan;34(1):20-2. PubMed PMID: 14959965. Epub 2004/02/13. eng.

18. Harris JB, Faiz MA, Rahman MR, Jalil MM, Ahsan MF, Theakston RD, et al. Snake bite in Chittagong Division, Bangladesh: a study of bitten patients who developed no signs of systemic envenoming. Transactions of the Royal Society of Tropical Medicine and Hygiene. 2010 May;104(5):320-7. PubMed PMID: 20096910. Epub 2010/01/26. eng.

19. Hati AK, Mandal M, De MK, Mukherjee H, Hati RN. Epidemiology of snake bite in the district of Burdwan, West Bengal. Journal of the Indian Medical Association. 1992 Jun;90(6):145-7. PubMed PMID: 1522302. Epub 1992/06/01. eng.

20. Bawaskar HS, Bawaskar PH. Profile of snakebite envenoming in western Maharashtra, India. Transactions of the Royal Society of Tropical Medicine and Hygiene. 2002 Jan-Feb;96(1):79-84. PubMed PMID: 11926002. Epub 2002/04/03. eng.

21. Cruz LS, Vargas R, Lopes AA. Snakebite envenomation and death in the developing world. Ethnicity \& disease. 2009 Spring;19(1 Suppl 1): S1-42-6. PubMed PMID: 19484874. Epub 2009/06/02. eng. 